logos_i_ethos_2016_(40)_numer_specjalny_1, s. 93-103

DOI: http://dx.doi.org/10.15633/lie.1701

Sylwia Zydek

Papieski Wydział Teologiczny we Wrocławiu

\title{
Radość człowieka cnotliwego, czyli o przyczynach radości w dobie saskiej
}

Współczesne myślenie o szczęściu i radości dookreśla wiele czynników. Można bowiem powiedzieć, iż istnieje mnóstwo „radosnych poruszeń serca" i całkiem sporo emocji „rodzących” szczęście. Wielość ta rodzi się z faktu, że obecnie o radości myślimy w bardzo zindywidualizowany sposób. Chcąc jednak mówić o przeżywaniu, odczuwaniu szczęścia w przeszłości, nie możemy myśleć kategoriami współczesnego człowieka, ponieważ ludzie żyjący w ubiegłych stuleciach przyczyny radości upatrywali głównie $\mathrm{w}$ Bogu. Pragnąc głębiej wniknąć w myślenie i odczuwanie „społeczeństw minionych epok", należy rozważania zacząć właśnie od próby zdefiniowania mentalności. Znakomity znawca tej tematyki, wrocławski historyk

Sylwia Zydek, dr, adiunkt w Papieskim Wydziale Teologicznym we Wrocławiu, Instytut Nauk Społecznych. Zainteresowania naukowe: historia mentalności, kultury (barok, oświecenie), historia Kościoła w dobie nowożytnej ze szczególnym uwzględnieniem znaczenia i roli zgromadzeń zakonnych w życiu społecznym, historia wychowania. Wybrane publikacje: Reformackie wizje eschatologiczne: Klemens Bolestwiusz (16251689) i Antoni Węgrzynowicz (1658-1721), [w:] Sic erat in fatis. Studia i szkice historyczne dedykowane Profesorowi Bogdanowi Rokowi, red. E. Kościk, R. Żerelik, F. Wolański, Toruń 2012; Trzy kobiety - trzy portrety (św. Brygida Szwedzka, św. Katrzyna ze Sieny, św. Teresa Benedykta od Krzyża, [w:] Portrety kobiecości, red. M. Jabłoński i in., Kraków 2014; Dialog Kościoła, rodziny i państwa jako gwarancja chrześcijańskiego wychowania na podstawie Divini illius Magistra, [w:] Wychowanie do dialogu. W poszukiwaniu modeli budowania relacji międzyludzkich, red. K. Jaworska, K. Wawrzynów, G. Sokołowski, Wrocław 2015. Bogdan Rok tak ją określa: „najogólniej mentalność oznacza sposób myślenia oparty na konkretnym, obowiązującym w danej społeczności systemie wartości, a z nim związany jest zespół charakterystycznych dla tej społeczności codziennych zachowań. Z socjologicznego 
i psychologicznego punktu widzenia mentalność stanowi pewną część świadomości społecznej”'. Badania dotyczące zachowań ludzkich w perspektywie szerszej niż ta, która nas otacza, dają szansę na zbadanie zjawisk społecznych w sposób permanentny, z racji widzenia ich znacznie wyraźniej i pełniej. Dlatego też należy zadać sobie trud i próbować wejść w odległą przestrzeń czasową, by zyskać odpowiedzi na stawiane sobie współcześnie pytania. Niekiedy z pomocą przychodzą nam tworzone obecnie definicje, które bardzo dobrze wyjaśnić mogą rzeczywistość historyczną, w omawianym przypadku - okresu baroku i oświecenia. W tym miejscu warto sięgnąć do ogólnych rozważań o szczęściu podejmowanych np. przez Władysława Tatarkiewicza, które mogą okazać się niezwykle pomocne w tłumaczeniu, czym było szczęście i gdzie szukał go człowiek doby saskiej: „W tym, co nazywamy zadowoleniem, jest nie tylko składnik uczuciowy, ale także składnik intelektualny; kto jest zadowolony, ten nie tylko się cieszy, ale także ocenia dodatnio to, z czego jest zadowolony. Właśnie dlatego określa się szczęście jako zadowolenie: jest nim bowiem ta sama dwoistość. [...] Ta dwoistość elementów zadowolenia tłumaczy tych ludzi, którzy powiadają, że są zadowoleni z życia, ale nie są szczęśliwi. To ci, w których rozszczepiły się dwa zwykłe elementy zadowolenia: uczuciowy i intelektualny, odczuwanie przyjemności życia i uznawanie jego wartości”2. Ta definicja w sposób niezwykle trafny pokazuje, jak pojmował szczęście człowiek doby saskiej, on to właśnie znajdował się w stanie permanentnego rozszczepienia elementów zadowolenia. Niejako bał się radości uczuciowej czy zmysłowej, choć szukał jej i bez wątpienia doświadczał. Zadowolenie intelektualne obejmowało głównie kwestie dotyczące spraw duchowych oraz tych, które związane były z doświadczeniem szczęścia trwałego, czyli zbawienia. Ludzie tego okresu mogli nawet czuć zadowolenie z życia, ale wiedzieli, że szczęście to kwestia raju. By dostać się do tego ostatniego, należało być cnotliwym i bezgrzesznym. Jak podpowiada kaznodzieja Antoni Węgrzynowicz,

1 B. Rok, Mentalność duchowieństwa polskiego w XVIII wieku, [w:] Studia z dziejów kultury i mentalności czasów nowożytnych, red. K. Matwijowski, B. Rok, Wrocław 1993, s. 10.

2 W. Tatarkiewicz, O szczęściu, Warszawa 1962, s. 40. 
wówczas można było liczyć na doświadczenie prawdziwej i niekończącej się eudajmonii: „Trojaka radość one błogosławione duchy uwesela i cieszy. Cieszą się rozkosznie z doskonałego i jasnego Boskiego poznania"3. Niebo jest zatem spełnieniem intelektualnym, duchowym i zmysłowym. Dlatego też tkwiąca w Bogu przyczyna radości stanowiła niejako jądro radości w ogóle. Miano bowiem świadomość, iż wszelkie uciechy, przyjemności, radości i szczęśliwe uniesienia, których doświadczano w codzienności, nie stanowiły bynajmniej jedynych i ostatecznych tego rodzaju doświadczeń. Dlatego też kierowano wzrok w kierunku wartości duchowych, głównie tych, które zapewniały uniesienia religijne. $\mathrm{W}$ religii, stałej i niezmiennej od wieków, poszukiwano radości, która miała się nigdy nie skończyć, i za taką tęskniono. Radość prawdziwa i jedyna miała być udziałem człowieka dopiero po śmierci. Analizując różnego rodzaju źródła historyczne, np. kazania, dzienniki podróży, widzimy wyraźnie, iż człowiek żyjący w XVIII wieku wiedział, że szczęścia nie znajdzie w tym, co go otacza, a co jest ulotne i efemeryczne, bo ziemskie, lecz w tym, co zakotwiczone jest w Bogu.

Nie da się jednak zaprzeczyć, że często i intensywnie czerpano radość $\mathrm{z}$ uciech życia doczesnego, nie stanowiło to bynajmniej życiowego marginesu magnaterii czy bogatszej szlachty. Rodzące radość i wytchnienie różnego rodzaju rozrywki ubogacały codzienność. Odnajdujemy tu pewną dychotomię, ponieważ deklaratywność sądów i opinii duchownych tamtej epoki pozostawała w sprzeczności z zachowaniami czy też pragnieniami społeczeństwa. Dochodziło zatem do konfrontacji poglądów wygłaszanych przez kaznodziejów z potrzebami i zachowaniami ludzi. Tu właśnie zaczynamy dotykać niezwykle ważnego pojęcia, o którym była już mowa, a mianowicie kwestii kształtowania mentalności. Jak podpowiada Tomasz Gałwiaczek: „Zderzenie kwestii deklaratywnych w aspekcie moralnym z estetycznymi (a także biologicznymi) funkcjami i potrzebami człowieka stanowiło jedną z podstawowych cech baroku. Znaczy to, iż mamy do czynienia z wizją społeczeństwa o gorących uczuciach religijnych do

3 A. Węgrzynowicz, Kazań niedzielnych księga trzecia o czterech rzeczach ostatecznych, Warszawa 1714, s. 137. 
Boga, Jezusa, Maryi, niezwykle afektywnym, wyrażanym żywiołowo, zarazem stojącym też w pewnej sprzeczności - przywiązanym do własnej cielesności, koncentrującym się na wrażeniach zmysłowych, estetycznych,

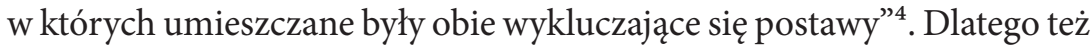
analizowana wyżej definicja Władysława Tatarkiewicza wydaje się niezwykle pomocna w zrozumieniu złożonej mentalnie postawy człowieka baroku w kontekście przeżywania szczęścia.

Analizując źródła dotyczące epoki, można spotkać wiele obrazów ilustrujących ludzkie życie tamtego okresu. Było ono bogate w wydarzenia, doświadczenia, emocje. Coś innego niż współcześnie budziło strach $^{5}$, wiele też innych powodów generowało radość ${ }^{6}$. Człowiek doby saskiej pożądał radości i szczęścia nie mniej intensywnie niż my dzisiaj, z tą jednak różnicą, że wiedział on, iż nie wszystko zależy od niego, miał świadomość swojej ograniczoności i skończoności. Nawet jeśli poszukiwał spełnienia w nauce, co w oświeceniu ${ }^{7}$ było dość powszechne, to i tak pozostawał w nie do końca rozumianej zależności od natury, której nie był w stanie pojąć i wytłumaczyć. Mógł gromadzić bogactwa, honory, ale musiał liczyć się z tym, iż stanie się niewolnikiem szatana i własnych egoistycznych skłonności ${ }^{8}$. I nic nie pomogło tłumaczenie, że bogactwo i powodzenie w życiu może być również oznaką bożego błogosławieństwa. Należy jednak uczciwe przyznać, że spora grupa mieszkańców ówczesnej Rzeczpospolitej lubowała się w zbytkach. Wystarczy wspomnieć choćby wspaniałe rezydencje biskupa Ignacego Krasickiego (zamek lidzbarski, pałac w Smolajnach oraz pałac we Fromborku). Biskup lubił węgierskie wino, piękne kwiaty w ogrodach, bale, przedstawienia

$4 \quad$ T. Gałwiaczek, Kształtowanie mentalności chrześcijanina w świetle kazań dominikańskich czasów saskich, Toruń 2009, s. 90.

5 J. Delumeau, Grzech i strach. Poczucie winy w kulturze Zachodu XIII-XVIII, Warszawa 1994; J. Delumeau, Strach w kulturze Zachodu XIV-XVIII, Warszawa 1986.

$6 \quad$ J. Dalke i in., Czym jest szczęście? Analiza na podstawie koncepcji Władysława Tatarkiewicza, „Analiza i Egzystencja” 21 (2013), s. 150.

$7 \quad$ W. Kaliszewski, Poznanie natury jako źródło przyjemności. Filozoficzne i poetyckie konteksty szczęścia, [w:] Przyjemność w kulturze epoki rozumu, red. T. Kostkiewiczowa, Warszawa 2011, s. $63 \mathrm{n}$.

8 T. Gałwiaczek, Kształtowanie mentalności..., dz. cyt., s. 92. 
teatralne, koncerty ${ }^{9}$. „Nasz karnawał skończy się niebawem, a spędziliśmy go tak wesoło, jak to tylko możliwe na wsi. Grano w teatrze zamkowym liczne komedie i przedstawienia bardzo się udały. Nasze bale są wesołe [...]" ${ }^{10}$. Chętnie zapraszał do siebie znanych i wysoko postawionych polityków czy dyplomatów, by wspomnieć choćby wizytę wielkiego księcia Pawła Piotrowicza i księcia pruskiego Henryka. Oczywiście nie tylko przedstawiciele duchowieństwa prowadzili życie nie zawsze naznaczone ascezą. Czytając relację z imienin Elżbiety Branickiej, również nabierzemy przekonania, że rozkosze i radości stołu obce dobie saskiej nie były: „Stół był zastawiony w galerii na 200 osób, w tym stole wzdłuż był kanał napełniony winem tokajskim, co niby wyobrażało morze, po tym winie płynęło 24 okręciki misternie zrobione, a na nich były pistacje, wszelkie cukry, konfitury i rozmaite łakocie. Takowe okręty zatrzymywały się przed damami i siedzącymi przy stole, które podług upodobania wybierały te przyjemne towary z okrętów. Po wetach przyniesiono ogromny puchar, który niegdyś był własnością Czarnieckiego, a goście czerpali nim owe tokajowe morze, które to całe morze w przeciągu pół godziny zniszczone zostało" ${ }^{\prime 1}$.

Należy zauważyć, że to właśnie w wieku XVIII próbowano złagodzić rygory postu, pojawiły się wyrafinowane potrawy i radość biesiadowania. Wtedy to przecież powstają pierwsze książki kucharskie ${ }^{12}$, jedzenie staje się przyjemnością, źródłem zadowolenia. Zapewne dlatego kaznodzieje, z taką lubością opisując rzeczywistość piekła i nieba, porównują je do uczty, gdzie serwowane będą przeróżne potrawy ${ }^{13}$. Nie wolno jednak

$9 \quad$ Por. S. Achremczyk, Życie codzienne na dworze biskupa Ignacego Krasickiego, [w:] Między barokiem a oświeceniem. Radości i troski dnia codziennego, red. S. Achremczyk, Olsztyn 2006, s. $159-176$.

10 Cyt. za: S. Achremczyk, Życie codzienne na dworze biskupa Ignacego Krasickiego, dz. cyt., s. 169.

11 Cyt. za: A. Raćko, Osiemnastowieczna przyjemność ucztowania na dworach magnackich, [w:] Przyjemność w kulturze epoki rozumu, dz. cyt., s. 195.

12 Drugą polską książką kucharską była pozycja wydana w 1783 roku Kucharz doskonały pożyteczny dla zatrudniających się gospodarstwem. J. Dumanowski, Kwestia smaku. Kulinarne fascynacje oświecenia, [w:] Przyjemność w kulturze epoki rozumu, dz. cyt., s. 181.

13 Wiele miejsca tym zagadnieniu poświecił również Antoni Wegrzynowicz. 
zapomnieć, że folgowanie sobie w kwestii postów rodzić mogło grzech obżarstwa i opilstwa, które były piętnowane przez ówczesną ambonę.

Poza strawą dla ciała zabiegano również o uniesienia duchowe, nie tylko te związane ze sferą religijną. Królował teatr ${ }^{14}$, a właściwie teatromania $^{15}$, bo teatry powstawały wszędzie, nawet na terenach szkół prowadzonych przez jezuitów czy pijarów i teatynów ${ }^{16}$. Lubowano się w balach, tańcach, baletach, widowiskach na wolnym powietrzu ${ }^{17}$. Jednak kaznodzieje, obserwując bawiących się wiernych, nie pozostawali obojętni. Antoni Węgrzynowicz gromi beztroskich tancerzy: „Wielu kroków razów stąpałeś w tańcu lubieżny taneczniku, tyle kroków do piekła uczyniłeś. Wszyscy tańczący niechybnie potępieni zostaną"18. Po raz kolejny wraca tu echo dychotomicznego myślenia o odczuwaniu szczęścia przez człowieka baroku. Z jednej strony beztroska i radosne uniesienia proponowane i popularyzowane nawet przez elity kościelne, z drugiej gromki głos zakonników wołających o życie w ascezie i cnocie, o porzucenie wszelkich ziemskich zabaw i rozrywek ${ }^{19}$.

Mimo surowych napomnień nie brakowało wcale osób, które, pozostając pod urokiem piękna doczesnego, zwracały uwagę na wygląd, modny strój. Szczególne „trendy modowe” trafiały nad Wisłę z Francji i również stawały się elementem odczuwania przyjemności ${ }^{20}$. Kaznodzieje, piętnując „modnisie”, posuwali się do przywoływania obrazów nad wyraz

14 Por. np. B. Judkowiak, Przyjemność w teoriach dramatyczno-teatralnych i jej osiemnastowieczne rewizje, [w:] Przyjemność w kulturze epoki rozumu, dz. cyt., s. 229-243.

15 K. Stasiewicz, Kobiece przyjemność w XVIII w., [w:] Przyjemność w kulturze epoki rozumu, dz. cyt., s. 125.

${ }_{16}$ I. Kadulska, Uroki widowiska pod obłokiem dla różnego stanu ludzi (niedziela 14 września 1788 w Eazienkach), [w:] Przyjemność w kulturze epoki rozumu, dz. cyt., s. 243.

17 Por. A. Norkowska, Miasto w literaturze: przestrzeń przyjemności „uczciwej” i „nagannej", red. T. Kostkiewiczowa, Warszawa 2011, s. 73-92; K. Malczewski, Dobra zabawa i rozrywka jako istotny element życia społeczno-kulturalnego szlachty polskiej w XVI-XVIII w., [w:] Z dziejów staropolskiej kultury i cywilizacji, red. K. Maliszewski, Lublin 2010, s. 101-106.

18 A. Węgrzynowicz, Kazań niedzielnych księga pierwsza to jest siedem trąb z objawienia Jana świętego przeciw siedmiu głównym grzechom, Kraków 1708, s. 151.

19 T. Gałwiaczek, Kształtowanie mentalności..., dz. cyt., s. 88.

20 Por. K. Puchowski, Rekreacja w elitarnych szkołach Europy epoki Oświecenia, [w:] Przyjemność w kulturze epoki rozumu, dz. cyt., s. 253-265. 
dosadnych. Cytowany przez Tomasza Gałwiaczka Aleksander Dowgiłło podaje przykład pewnej kobiety nadto dbającej o wygląd zewnętrzny, która miała zostać zamieniona w klacz: „niektóremu gospodarzowi żona przemieniła się w klacz. Wielki wstyd i frasunek męża" ${ }^{21}$. Trudno wyobrazić sobie większe nieszczęście i kłopot.

Kolejną sytuacją, która budziła radość, były z pewnością podróże, te edukacyjne młodych magnatów oraz te, które noszą miano podróży religijnych, czyli pielgrzymki. Bardzo interesujący opis podróży, która mogła wprawić w zachwyt i intensywnie radować, pozostawiła Teofila Konstancja z Radziwiłłów Morawska. W latach 1773-1774 odbyła ona podróż po Europie. Zwiedziła Niemcy, Francję i Włochy. To, co widziała i co co budziło jej emocje, opisywała dość szczegółowo, podkreślając też uczucie radości, której doznawała na widok piękna otaczającego ją świata ${ }^{22}$.

Podróże odbywali również duchowni. Mogli udawać się na pielgrzymki do świętych miejsce. Albo stawić się na kapituły generalne swych zgromadzeń zakonnych, z których większość odbywała się w Rzymie. Opisem, który pozostał z takiej wyprawy, jest m.in. Opisanie podróży rzymskiej na kapitułe generalska autorstwa Ignacego Stanisława Filipeckiego ${ }^{23}$. $\mathrm{Z}$ dokumentu tego bije zakonna asceza i prostota. Trudno w nim odnaleźć emocjonujące, pełne radości opisy zjawisk, zabytków. Napotykany tam raczej na relacje $z$ nabożeństw i opisy świętych relikwii. Podobne wrażenie można odnieść, czytając relację Wacława Sierakowskiego z podróży do Rzymu w roku $1763^{24}$. Radość z obcowania z piękną, nieznaną przyrodą, dziedzictwem historycznym, zabytkami była w relacjach osób duchownych mało eksponowana, schodziła na plan dalszy, bo pierwsze miejsce zajmowały radości „generowane” przez sferę duchowo-religijną, czyli święte obrzędy, nabożeństwa, pamiątki, relikwie. Nie szukano tam

21 T. Gałwiaczek, Kształtowanie mentalności..., dz. cyt., s. 101.

22 Teofila Konstancja z Radziwiłłów Morawska, Diariusz z podróży 1773-1774, wstęp i oprac. B. Rok, Wrocław 2002, s. 163.

${ }^{23}$ Por. B. Rok, Świat kultury staropolskiej. Teksty źródłowe i studia, Toruń 2014, s. 7-39.

24 Por. B. Rok, Opisanie podróży Wacława Sierakowskiego (1741-1806) po Europie w latach 1763-1769, [w:] Z badań nad Rzeczpospolita w czasach nowożytnych, red. K. Matwijowki, Wrocław 2001, s. 131-148. 
europejskich rozrywek, zbytków, podniet. Kluczem w rozumieniu tych podróży zdaje się właśnie radość duchowa, metafizyczno-mistyczna, skierowana na Boga.

Chcąc analizować głębiej zjawisko odczuwania, przeżywania radości i szczęścia, należy zaznaczyć, iż mimo ostrej krytyki ze strony duchownych, trudno nie przyznać, że poszukiwanie bogactw, majątków, dostatku, rozrywek czy strojów stanowiło ogromną wartość, popychało człowieka do działań niekiedy sprzecznych z chrześcijańskimi cnotami ${ }^{25}$.

Rodziło to wspominany wcześniej dualizm, pomiędzy radością ziemi i nieba, z pozoru trudny do pogodzenia. Można było odczuwać radość chwilową, zawsze jednak myśli dążyły ku temu, co nienaznaczone czasowością. Warto przytoczyć tu jeszcze Pamiętnik na podstawie rękopisu pisanego w latach 1737-1790 autorstwa Walentego Klichowskiego, którego bez wahania nazwać można „radosnym cnotliwym”. Zauważamy bez trudu, iż autor, pisząc o wielu istotnych dla siebie kwestiach ${ }^{26}$, najwięcej uwagi poświęca „radości” przychodzenia na świat swoich dzieci, których doczekał się dwanaściorga. $Z$ tego wnioskować możemy, iż było to dla niego doświadczenie niezwykle istotnie, rodzące radość właśnie, choć w całym pamiętniku w zasadzie nie używa tego słowa. Mówi jedynie o pożegnaniu swego zmarłego brata: „abyśmy się w świętej cieszyli wieczności”27. Tylko raz czytamy: „I mnie tam czekać będą, aby jakośmy w życiu szczęśliwi byli i po śmierci nie byli od siebie rozłączeni, czekając powszechnego powstania na Dolinie Jozafata"28. Z wypowiedzi tej wyłania się obraz spełnionego małżonka, który dochował wierności żonie, świętym sakramentom, który był ojcem licznej gromadki (choć sześcioro dzieci zmarło we wczesnym dzieciństwie), żył zgodnie z przykazaniami, a zatem zasłużył na radość i szczęście, którego okruchami karmił się już na ziemi, o czym również wspomina. Oto człowiek, który wiedział, rozumiał, że z życia można być zadowolonym, ale na szczęście

\footnotetext{
25 T. Gałwiaczek, Kształtowanie mentalności..., dz.cyt., s. 97.

26 Wspomina np. o podróżach do krewnych, interesach, szarańczy, kościelnych jubileuszach.

27 B. Rok, Świat kultury staropolskiej..., dz. cyt., s. 29.

28 B. Rok, Świat kultury staropolskiej..., dz. cyt., s. 33.
} 
warto poczekać, by doświadczać go po śmierci. Właśnie dlatego wszystkie radości i uciechy w kontekście nadziei na ostateczną eudajmonię blakły znacząco: „Cokolwiek świat swoich może mieć uciech, wszystko to jedno piękne nic nazwać nie może respektem Boskim. Uciecha światowa, uciechą jest $\mathrm{z}$ samego imienia tylko, ale co w samej rzeczy to jest prawdziwy smutek. [...] W uciechach światowych, płacz się z śmiechem pospołu miesza i każda wesołości płaczem się kończy" - tak oto dobitnie puentuje rozważania o radości ziemskiej cytowany przez Tomasza Gałwiaczka Rajmund Czaszyński, barokowy kaznodzieja ${ }^{29}$. Taki właśnie ton kazań pokazywał wyraźnie, co jest faktyczną radością, czyli wartością niepodlegającą działaniu czasu.

Życie w zgodzie z przykazaniami, ćwiczenie się w cnocie, asceza miały gwarantować osiągniecie radości prawdziwej w rzeczywistości eschatologicznej. Warto zwrócić również uwagę, że człowiek barokowy, doświadczając radości, dotykał jej w trudnej dziś do przyjęcia perspektywie, czyli w perspektywie śmierci. Dobre do niej przygotowanie właśnie przez ćwiczenie się w cnotach, unikanie grzechu, wstrzemięźliwość, pobożność przyjmowanie sakramentów dawało pewność, że śmierć nie będzie doświadczeniem bolesnym i niosącym potępienie. Pobierano swoiste lekcje dobrej śmierci (np. uczestnicząc w pogrzebach), czytano poradniki artis bene moriendi, bo śmierć nie pozostawała w strefie przeżyć intymnych, nie była tematem tabu ${ }^{30}$. Śmierć niejako „żyła” obok, a w przekazie kaznodziejskim definiowana była dwojako - w kontekście szczęścia i radości (śmierć błogosławiona cnotliwych) oraz w perspektywie potępienia i zatracenia. Wybór zatem wydawał się oczywisty, człowiek marzył o śmierci radosnej, błogosławionej, czyli właśnie szczęśliwej, takiej wyczekiwał. Wiedział, że wiele zależy od niego, że sam jest twórcą swego życia i swojej śmierci, wiedział, że musi się należycie przysposobić do odchodzenie z tego świata, by doświadczyć śmierci szczęśliwej.

Zatem żadna doczesna radość, odczuwanie szczęścia, jakkolwiek mocno było pożądane, nie mogło w sposób trwały zapewnić spełnienia i ukoić 
tęskniącego za pełną radością serca. To mogło sprawić tylko życie cnotliwe, które niosło w konsekwencji dobrą, szczęśliwą śmierci i prawdziwe, jedyne, trwałe szczęście w raju.

\section{Bibliografia}

Achremczyk S., Życie codzienne na dworze biskupa Ignacego Krasickiego, [w:] Między barokiem a oświeceniem. Radości i troski dnia codziennego, red. S. Achremczyk, Olsztyn 2006.

Dalke J. i in., Czym jest szczęście? Analiza na podstawie koncepcji Władysława Tatarkiewicza, „Analiza i Egzystencja” 21 (2013), s. 149-160.

Delumeau J., Strach w kulturze Zachodu XIV-XVIII, tłum. A. Szymanowski, Warszawa 1986.

Delumeau J., Grzech i strach. Poczucie winy w kulturze Zachodu XIII-XVIII, thum. A. Szymanowski, Warszawa 1994.

Dumanowski J., Kwestia smaku. Kulinarne fascynacje oświecenia, [w:] Przyjemność w kulturze epoki rozumu, red. T. Kostkiewiczowa, Warszawa 2011.

Gałwiaczek T., Kształtowanie mentalności chrześcijanina w świetle kazań dominikańskich czasów saskich, Toruń 2009.

Judkowiak B., Przyjemność w teoriach dramatyczno-teatralnych i jej osiemnastowieczne rewizje, [w:] Przyjemność w kulturze epoki rozumu, red. T. Kostkiewiczowa, Warszawa 2011.

Kadulska I., Uroki widowiska pod obłokiem dla różnego stanu ludzi (niedziela 14 września 1788 w Łazienkach), [w:] Przyjemność w kulturze epoki rozumu, red. T. Kostkiewiczowa, Warszawa 2011.

Kaliszewski W., Poznanie natury jako źródło przyjemności. Filozoficzne i poetyckie konteksty szczęścia, [w:] Przyjemność w kulturze epoki rozumu, red. T. Kostkiewiczowa, Warszawa 2011.

Malczewski K., Dobra zabawa i rozrywka jako istotny element życia społeczno-kulturalnego szlachty polskiej w XVI-XVIII w., [w:] Z dziejów staropolskiej kultury i cywilizacji, red. K. Maliszewski, Lublin 2010.

Norkowska A., Miasto w literaturze. Przestrzeń przyjemności „uczciwej” i „nagannej”, red. T. Kostkiewiczowa, Warszawa 2011. 
Radość człowieka cnotliwego, czyli o przyczynach radości w dobie saskiej 103

Puchowski K., Rekreacja w elitarnych szkołach Europy epoki Oświecenia, [w:] Przyjemność w kulturze epoki rozumu, red. T. Kostkiewiczowa, Warszawa 2011.

Raćko A., Osiemnastowieczna przyjemność ucztowania na dworach magnackich, [w:] Przyjemność w kulturze epoki rozumu, red. T. Kostkiewiczowa, Warszawa 2011.

Rok B., Człowiek wobec śmierci w kulturze staropolskiej, Wrocław 1995.

Rok B., Mentalność duchowieństwa polskiego w XVIII wieku, [w:] Studia z dziejów kultury i mentalności czasów nowożytnych, red. K. Matwijowski, B. Rok, Wrocław 1993.

Rok B., Opisanie podróży Wacława Sierakowskiego (1741-1806) po Europie w latach 17631769, [w:] Z badań nad Rzeczpospolitą w czasach nowożytnych, red. K. Matwijowki, Wrocław 2001.

Rok B., Świat kultury staropolskiej. Teksty źródłowe i studia, Toruń 2014.

Stasiewicz K., Kobiece przyjemność w XVIII w., [w:] Przyjemność w kulturze epoki rozumu, red. T. Kostkiewiczowa, Warszawa 2011.

Tatarkiewicz W., O szczęściu, Warszawa 1962.

Teofila Konstancja z Radziwiłłów Morawska, Diariusz z podróży 1773-1774, wstęp i oprac. B. Rok, Wrocław 2002.

Węgrzynowicz A., Kazań niedzielnych księga pierwsza to jest siedem trąb z objawienia Jana świętego przeciw siedmiu głównym grzechom, Kraków 1708.

Węgrzynowicz A., Kazań niedzielnych księga trzecia o czterech rzeczach ostatecznych, Warszawa 1714. 